\title{
'Joint Action' Attracting people through signs: Linguistic Landscape on Banking Sign in Malang City, Indonesia
}

\author{
Sumarlam $^{1}$, Dwi Purnanto², Dany Ardhian ${ }^{3}$ \\ ${ }^{1,2}$ Faculty of Cultural Science, Universitas Sebelas Maret, Indonesia \\ ${ }^{3}$ Linguistics Post-Graduate Program, Faculty of Cultural Science, \\ Universitas Sebelas Maret, Indonesia \\ ${ }^{1}$ sumarlam@staff.uns.ac.id \\ 22dwipurnanto@staff.uns.ac.id \\ ${ }^{3}$ danyardhian@ub.ac.id, danyardhian@student.uns.ac.id
}

\begin{abstract}
Linguistic Landscape is the study of language that identifies texts in public space. This study aims to investigate the sign of the banking institution. The research location was taken in Malang City, Indonesia. The research data weretaken from the text on 149 signboards of banking, cooperation, and financial institutions using photography. The results showed that there were three patterns of language use, namely monolingual, bilingual, and multilingual. The use of the language involves six languages, namely Bahasa Indonesia, English, Arabic, Javanese, Chinese, and Sanskrit. Indonesian dominates text in public spaces, followed by English, and Arabic, and other languages. Bahasa Indonesia carries a symbol of language policy and linguistic competence; English builds modern, global, and prestige; Arabic reinforces Islamic symbols by building differentiation between the Islamic and conventional banking systems; Javanese develops symbols of local wisdom, culture, and solidarity; Sanskrit builds historical symbols of the glories of the past which are still relevant today.
\end{abstract}

Keywords: Linguistic landscape; banking; Malang City; Indonesia

\section{Introduction}

Banking is growing rapidly now along with the development of the digital world and the rate of economic growth. Everyone must be in touch and need banking services. Banking provides various facilities for the community in economic needs, both transferring services, deposits, business financing, and savings and loans. Since 1992, Indonesia has introduced a dual banking system, namely the conventional and sharia system 'Islamic Bank' ([1]. Conventional banks adopt the banking system in general, while the sharia system refers to Islamic legal agreements between banks and other parties by prohibiting bank interest (riba), gambling (masyir), and obscurity (gharar). Conventional banks operate based on bank interest, while Islamic banks operate based on profit sharing, buying and selling, and leasing. Both of these systems are played by the government and the private sector. In the next process, the two systems were adopted by these banks simultaneously. For example, the Bank Nasional Indonesia 'National Bank of Indonesia ' (BNI) adopts conventional BNI and BNI Shariah.

With Indonesia's Muslim majority population, Islamic banking (sharia) is growing rapidly. To distinguish conventional and sharia systems, banking owners give a certain identity to the name of the bank. This pattern is commonly applied in Indonesia by adding the word 
'sharia'. To emphasize these differences, the name of the banking institution also uses Islamic terms.

\section{Linguistic Competence}

The city of Malang, Indonesia, is inhabited by a majority of Javanese ethnic groups, a minority of Madurese, Arab and Chinese descendants, and other ethnic minorities. With its educational appeal, business center, tourism, and health, Malang City has become an urban city. This condition makes Malang people's linguistic competence familiar with various languages. Javanese is a regional language that is spoken orally between residents. A minority of minority communities use traditional languages among themselves, such as Madurese.

In government, education, and business, Bahasa Indonesia as the national language is used both in oral and written communication. English is only used in certain domains which are very limited because the people's competence in English is also very limited. Whereas Arabic is only used by ethnic Arab communities, but not by non-Arab Muslims. With this condition, the banking naming system naturally adopts many considerations, such as linguistic competence, community ideology, language policy, and banking interests themselves.

\section{Linguistic Landscape}

Linguistic Landscape (hereinafter LL) is a language analysis applied to text analysis in public spaces, such as street boards, advertisements, billboards, shop names, place names, names of government buildings within an area [2]. These signs provide information on the identity of the place name. Besides, the use of language also contains certain symbols. Therefore, language selection is carried out with various considerations, including slipping power symbols through language. This symbolic function seeks to expose how ideology and culture are expressed through language at a given place[3]. Calculation of the frequency of language use whether monolingual, bilingual, or multilingual is a mechanism to investigate how functions are built, both information and symbolic functions so that the power and status of a language will be seen.

Some LL researchers have reported the results of studies, such as [4], [5] [6], [7], [8], [9], [10], [11], [12], [13], [14], [15], [16], [5], and [17]. LL research was also held in Indonesia, including [18] [19], [20], [21],[22], [23].

\section{Method}

The research location is in the city of Malang, Indonesia with data taken from a number of highways. The research data were obtained from 149 signs that were divided into the bank, cooperative, and finance ownership marks both government and private. Data were taken through photography. The same sign is only taken one. Data analysis uses Landscape Linguistics by classifying data based on Top-Down and Bottom-Up, monolingual, bilingual, and multilingual frequency, information, and symbolic functions. 


\section{Result and Discussion}

\section{Frequency of Language Usage: Top-Down Sign}

The Top-Down pattern is also called the official sign where this sign is made by the government [24]. In the findings, there are not many state-owned banks (7 signs). That is because there is a sign that appears several times in different regions (which are considered the same and taken only one). In general, the state-owned banks have branches. This condition is different from the more varied private banks, both branches, different banks, and types of banking, such as cooperatives and finance.

Table 1. Frequency of Top-Down Sign

\begin{tabular}{lll}
\hline Top-Down Sign & & \\
\hline Monolingual & Bilingual & Multilingual \\
\hline Ind & Ind+Arab & -- \\
\hline 6 & 1 & 0 \\
\hline
\end{tabular}

Table 1 shows that there were only 7 signs on the Top-Down in the area under study. The dominance of the Indonesian language in the sign indicates the presence of language policy in the sign regulation system. Whereas other languages that can attend the Top-Down sign are only Arabic.

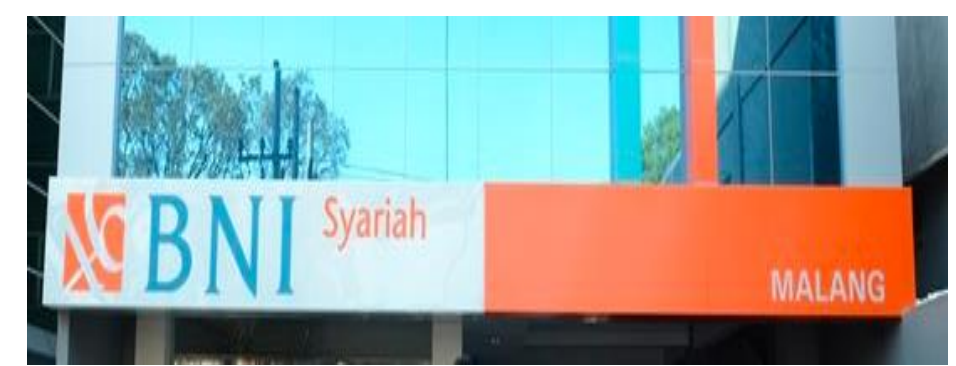

Figure 1. Bahasa Indonesia+ Arabic in Bilingual Sign

Bank BNI implements a dual system, both conventional and sharia. Figure 1 shows the presence of Arabic (Sharia) in Top-Down banking. The emergence of the name of sharia gives identity to the needs of the community towards the world of sharia banking. With the majority of the Muslim community in Malang City, the presence of Islamic banking is needed as an alternative to conventional banks that are considered incompatible with Islamic law because they are considered to contain the usury system.

Table 2. Frequency of Bottom-Up Sign

\begin{tabular}{|c|c|c|c|c|c|c|c|c|c|}
\hline \multicolumn{10}{|c|}{ Bottom-Up } \\
\hline \multicolumn{2}{|c|}{ Monolingual } & \multicolumn{5}{|c|}{ Bilingual } & \multicolumn{3}{|c|}{ Multilingual } \\
\hline Ind & Eng & $\begin{array}{l}\text { Ind+E } \\
\text { ng }\end{array}$ & $\begin{array}{l}\text { Ind+ } \\
\text { Java }\end{array}$ & $\begin{array}{l}\text { Ind+ } \\
\text { Arab }\end{array}$ & $\begin{array}{l}\text { Ind+C } \\
\text { hin }\end{array}$ & $\begin{array}{l}\text { Ind+ } \\
\text { Sansk }\end{array}$ & $\begin{array}{l}\text { Ind+Eng } \\
+ \text { Java }\end{array}$ & $\begin{array}{l}\text { Ind+Jav } \\
+ \text { Arab }\end{array}$ & $\begin{array}{l}\text { Ind+Eng } \\
+ \text { Sanskrit }\end{array}$ \\
\hline 77 & 10 & 11 & 20 & 16 & 1 & 3 & 1 & 2 & 1 \\
\hline $54.2 \%$ & $7.1 \%$ & $7.7 \%$ & $14.1 \%$ & $11.3 \%$ & $0.7 \%$ & $2.1 \%$ & $0.7 \%$ & $1.4 \%$ & $0.7 \%$ \\
\hline
\end{tabular}


Table 2 shows the presence of three forms of language use (monolingual, bilingual, multilingual) involving six languages, namely Bahasa Indonesia, English, Javanese, Arabic, Chinese, and Sanskrit. Bahasa Indonesia is involved in all forms. The monolingual form gives rise to two languages (Bahasa Indonesia and English, bilingual gives rise to six languages (Bahasa Indonesia, English, Javanese, Arabic, Chinese, and Sanskrit). The multilingual form gives rise to five languages (Bahasa Indonesia, English, Javanese, Arabic, and Sanskrit). Monolingual Bahasa Indonesia dominates the frequency of occurrence (54.2\%), while bilingual is dominated by a combination of Bahasa Indonesia and Javanese (14.1\%) followed by a combination of Bahasa Indonesia-English (7.7\%). The multilingual form is controlled by a combination of Bahasa Indonesia-Javanese + Arabic). This finding indicates that the need for using Bahasa Indonesia is very high in banking, in addition to accommodating local languages, foreign languages, and other languages. This finding is also an indicator that Bahasa Indonesia can collaborate in 'joint action' with other languages.

\section{The symbolic sign of Bahasa Indonesia}

Bahasa Indonesia is the national language, the lingua franca, the official language, and the language of the country. The identity of Bahasa Indonesia is strengthened by the presence of language policies ranging from growth, care, teaching, and the use of Bahasa Indonesia in public spaces. That identity makes Bahasa Indonesia is a strong language. That power is supported by the competence of Bahasa Indonesia speakers who are high and growing, even tending to threaten the local language (language leakage). From its profit position, banks try to use it to attract customers by introducing a bank name and educating products and services. This linearity makes Bahasa Indonesia master "supply chain" in banking terms. Through language policy, English terms are adapted into Bahasa Indonesia or made bilingual.

The strong community linguistic competence of Bahasa Indonesia makes this language has power and status. This is also supported by the language policy that places Bahasa Indonesia as the official language in the public sphere. Various rules are made to mark the power of government through language. Through language policy, Bahasa Indonesia can dominate regional languages and foreign languages in public spaces [23]. This condition can be seen from the findings (tables 1 and 2) where Bahasa Indonesia is not only involved in the text structuring system in banking names, but also dominates it. This combination of linguistic competence with language policy builds up a certain social status and prestige. This finding confirms the findings of [25], that national language plays an important role in building status and prestige.

\section{Promoting internationalism, modernism, prestige, and global trough English sign}

English has an aura of being a prestigious language and building an international image [26]. English is also able to satisfy international needs, especially in tourism [27]. English is considered to build high prestige as a modern symbol and progress of social status (Yuan, 2008). 
English is also a symbol of globalization [28]. The global symbol is seen because many English are found throughout the world [29]. From that opinion, English contributes to building international, global, modern, and prestige symbols.

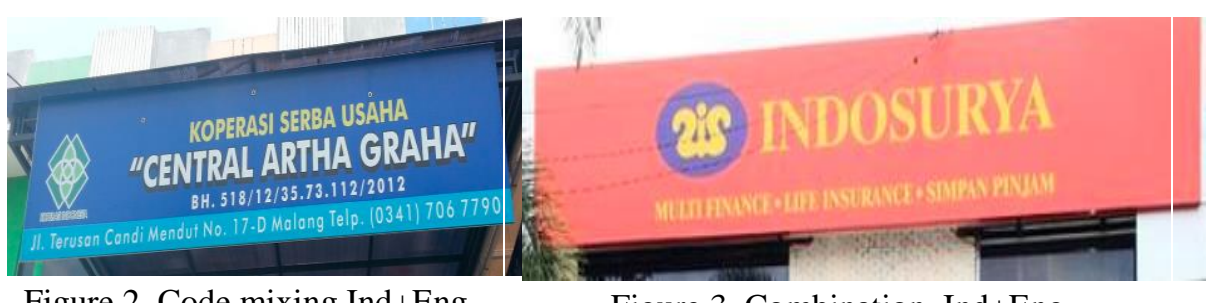

Figure 2. Code mixing Ind+Eng

Figure 3. Combination Ind+Eng

Figures 2 and 3 show that English can form different structures in signs. English builds a mixed code (Figure 2). The word "central" has been adopted by the Indonesian language "sentral". However, the signwriter prefers English to Bahasa Indonesia as well as figure 3. Status symbols are built-in figure 2. Cooperatives are banking institutions for the lower middle class to raise status but still maintain linguistic competence. English and Bahasa Indonesia joined in the joint action. The symbol built by figure 3 is different from figure 2 which further emphasizes modern and global elements. Modern for the banking system that is used and global because multi finance and insurance services have developed in the global world. This English status will continue to improve and its function will be highlighted in the future[7].

\section{Combination: Bilingual and Multilingual Sign}

The combination structure by choosing another language is motivated by combining the access and strengths of each language. The joint action will produce a double impact. The strong role of Bahasa Indonesia is used by other languages in building "joint action". This finding shows that Bahasa Indonesia, English, Javanese, and Arabic are combined to fill public spaces in banking. Demographic factors and sociolinguistic conditions of Malang people trigger the emergence of the use of these languages. In addition, the need for the community is also taken into account, related to the sharia system, modern and global promotion, and local wisdom. 


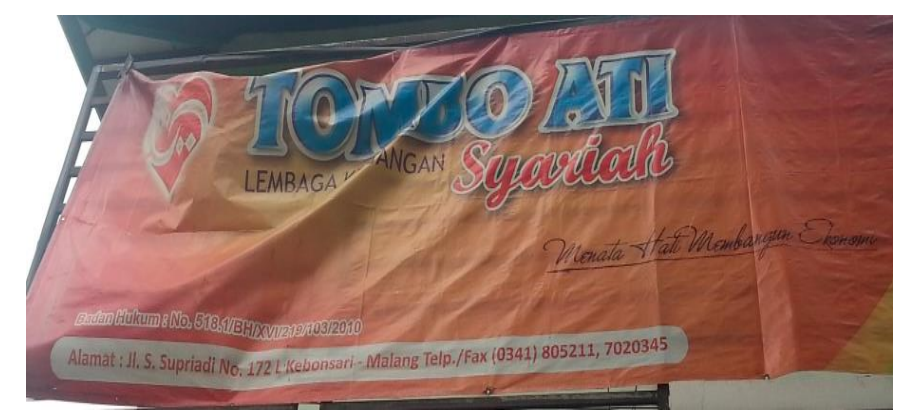

Figure 4. Multilingual sign by three language combination

Malang is dominated by Javanese ethnicity. They are spread in five districts, namely Lowokwaru, Blimbing, Klojen, Kedung Kandang, and Sukun. In addition to the dominance of demographics by Javanese ethnic groups, the dominance of Muslim communities also plays an important role. Malang City is inhabited by a majority of the Muslim population. This condition also determines the role of bank needs in serving customers. Meanwhile, conventional banks are currently considered to contain the usury system. By Islam, usury is considered haram so it must be abandoned. Therefore, banking also adjusts its service systems. In total there were 19 (12.8\%) signs involving Arabic with the use of Islamic lexicon with the most appearances in the Bottom-Up pattern.

Figure 4 shows the joint action between linguistic competence, Islamic ideology, and local wisdom. Javanese in "Tombo Ati" is combined with Bahasa Indonesia in the text "Lembaga Keuangan" and the Arabic term "Syariah". The symbols were exhibited to attract the public to use the services of these financial institutions. The target market is Javanese, Muslim, and lowermiddle-class people. The "combination game" will form a new stigma as a modern financial institution, Islamic, and showing Javanese interethnic solidarity and local wisdom through Javanese quotes.

\section{Conclusion}

Language contestation in public spaces contains elements of language competition and symbols. Information conveyed in a sign will be more enticing to the public by using several languages. This joint action seeks to attract people to enjoy banking services. The language policy symbol and linguistic competence in Bahasa Indonesia are very strongly utilized by English with modern, status, and global symbols. Besides, Javanese as an ethnic and regional language also carries the mission of local wisdom and solidarity. Regional languages have a goal to build culture and solidarity with local customers [3]. This is used by banking to attracting customers. The popular Javanese motto is an effective strategy as a trigger in attracting ethnic Javanese people.

The collaboration of symbols is played by the signwriter to attract as many community variants as possible. Community trends in Islamic banking are accommodated in public spaces. 
The emergence of the term "sharia" aims to strengthen the symbol as well as a strategy of differentiation over the conventional banking system. In addition, the presence of Sanskrit carries a symbol of cultural and historical preservation. Sanskrit is no longer used both in oral and written. This language became an important historical part of society with the glory of the Singosari Kingdom in the past (1222-1293 AD). The strength of the glory symbol is still relevant to current conditions. This language game also intends to anticipate banking conditions in the future so that banking institutions can still exist and be trusted by the public. The macro finding in this analysis is that language policy plays a major role in the choice of language in banking spaces. With its strengths, Bahasa Indonesia invites other languages for joint action in attracting people to involve in banking services.

\section{Acknowledgment}

The research team would like to thank the UNS Institute for Research and Community Service (LPPM-UNS) for funding this research.

\section{References}

[1] A. Diana Yumanita, Bank Syariah: Gambaran Umum PUSAT, vol. 14, no. 14. 2010.

[2] S. Psychology, R. L. Universit, R. B. Universit, and R. Bourhis, "Linguistic Landscape and Ethnolinguistic VitalityAn Empirical Study," no. December 2013, 1997, doi: 10.1177/0261927X970161002.

[3] M. Yuan, "Submission and resistance in the English linguistic landscape of Chaoshan," English Today, vol. 35, no. 2, pp. 20-28, Jun. 2019, doi: 10.1017/S0266078418000214.

[4] G. A. Martínez, "Vital Signs: A photovoice assessment of the linguistic landscape in Spanish in healthcare facilities along the U.S.-Mexico border," Int. J. Commun. Heal., no. 1, 2016, [Online]. Available: http://communicationandhealth.ro/upload/number4/GLENN-A-MARTINEZ.pdf.

[5] M. V. Calvi and M. Uberti-Bona, "Negotiating languages, identities and space in Hispanic linguistic landscape in Milan," J. Multiling. Multicult. Dev., vol. 41, no. 1, pp. 25-44, Jan. 2020, doi: 10.1080/01434632.2019.1622709.

[6] L. Hoffman, "Pharmaceuticals and tourist spaces: Encountering the medicinal in cozumel's linguistic landscape," Acme, vol. 16, no. 1, pp. 59-88, 2017.

[7] S. Wang, "Discourses in Place: Language in the Material World," J. Pragmat., vol. 37, no. 5, pp. 769-773, 2005, doi: 10.1016/j.pragma.2004.03.005.

[8] B. Lado, "Linguistic landscape as a reflection of the linguistic and ideological conflict in the valencian community," Int. J. Multiling., vol. 8, no. 2, pp. 135-150, 2011, doi: 10.1080/14790718.2010.550296.

[9] P. Backhaus, "Multilingualism in tokyo: A look into the linguistic landscape," Int. J. Multiling., vol. 3, no. 1, pp. 52-66, 2006, doi: 10.1080/14790710608668385.

[10] A. Bruyèl-Olmedo and M. Juan-Garau, "Shaping tourist LL: language display and the sociolinguistic background of an international multilingual readership," Int. J. Multiling., vol. 12, no. 1, pp. 51-67, 2015, doi: 10.1080/14790718.2013.827688.

[11] A. Bruyèl-Olmedo and M. Juan-Garau, "English as a lingua franca in the linguistic landscape of the multilingual resort of S'Arenal in Mallorca," Int. J. Multiling., vol. 6, no. 4, pp. 386-411, 2009, doi: 10.1080/14790710903125010.

[12] A. Bruyèl-Olmedo, M. Juan-Garau, B. A. ah Chiatoh, G. Chiro, and P. Coluzzi, "The 
italian linguistic landscape: The cases of Milan and Udine," Int. J. Multiling., vol. 11, no. 3, pp. 51-67, 2014, doi: 10.1080/14790718.2014.921179.

[13] H. W. Amos, "Regional language vitality in the linguistic landscape: hidden hierarchies on street signs in Toulouse," Int. J. Multiling., vol. 14, no. 2, pp. 93-108, 2017, doi: 10.1080/14790718.2015.1103244.

[14] M. H. Amara, "Palestinian schoolscapes in Israel," no. May, 2018, doi: 10.1186/s40862-018-0047-1.

[15] A. Nikolaou, "Mapping the linguistic landscape of Athens: the case of shop signs," Int. J. Multiling., vol. 14, no. 2, pp. 160-182, 2017, doi: 10.1080/14790718.2016.1159209.

[16] J. Ruzaite, "The linguistic landscape of tourism: Multilingual signs in Lithuanian and polish resorts," Eesti ja Soome-Ugri Keeleteaduse Ajak., vol. 8, no. 1, pp. 197-220, 2017, doi: 10.12697/jeful.2017.8.1.11.

[17] S. A. Manan, M. K. David, F. P. Dumanig, and K. Naqeebullah, "Politics, economics and identity: mapping the linguistic landscape of Kuala Lumpur, Malaysia," Int. J. Multiling., vol. 12, no. 1, pp. 31-50, 2015, doi: 10.1080/14790718.2014.905581.

[18] E. Oktaviani, "LINGUISTIC LANDSCAPE: A CASE STUDY OF SHOP NAMES IN GRESIK KOTA BARU (GKB), GRESIK," 2019.

[19] N. Yannuar and S. E. Tabiati, "Public signs in the city of Malang: A study on the linguistic landscape of Indonesia," Chang. face Lang. Pedagog. Explor. Linguist. Lit., no. June, pp. 123-138, 2016.

[20] E. Andriyanti, "Linguistic landscape at Yogyakarta's senior high schools in multilingual context: Patterns and representation," Indones. J. Appl. Linguist., vol. 9, no. 1, pp. 85-97, 2019, doi: 10.17509/ijal.v9i1.13841.

[21] F. Erikha, "Konsep Lanskap Linguistik Pada Papan Nama Jalan Kerajaan (Râjamârga): Studi Kasus Di Kota Yogyakarta,” Paradig. J. Kaji. Budaya, vol. 8, no. 1, p. 38, 2018, doi: 10.17510/paradigma.v8i1.231.

[22] S. Sumarlam, D. Purnanto, and D. Ardhian, "Will Ideology Compete or Unite? Form and Function of Linguistic Landscape of Public and Private School in Malang City, East Java," in Advances in Social Science, Education and Humanities Research, volume 338 Fifth PRASASTI International Seminar on Linguistics (PRASASTI 2019), 2019, doi: 10.2991/prasasti-19.2019.49.

[23] Sumarlam, "Linguistic Landscape of Food Stall and Restaurant Names: A Supply Chain Management of Halal Food in Malang City, Indonesia," Int. J. Supply Chain Manag., vol. 9, no. 2, pp. 700-705, 2020, [Online]. Available: https://ojs.excelingtech.co.uk/index.php/IJSCM/article/view/4680.

[24] J. Cenoz and D. Gorter, "Linguistic Landscape and Minority Languages Linguistic Landscape and Minority Languages," vol. 0718, no. 2006, 2008, doi: 10.1080/14790710608668386.

[25] S. H. Mirvahedi, "Linguistic landscaping in Tabriz, Iran: A discursive transformation of a bilingual space into a monolingual place," Int. J. Soc. Lang., vol. 2016, no. 242, pp. 195-216, Nov. 2016, doi: 10.1515/ijsl-2016-0039.

[26] P. Coluzzi, "The linguistic landscape of Brunei," World Englishes, vol. 35, no. 4, pp. 497-508, Dec. 2016, doi: 10.1111/weng.12221.

[27] R. Xiao and C. Lee, "English in the linguistic landscape of the Palace Museum: a field-based sociolinguistic approach," Soc. Semiot., 2019, doi: 10.1080/10350330.2019.1697542.

[28] L. Rowland, "English in the Japanese linguistic landscape: a motive analysis," $J$. 
Multiling. Multicult. Dev., vol. 37, no. 1, pp. 40-55, Jan. 2016, doi: 10.1080/01434632.2015.1029932.

[29] D. Gorter, "Linguistic landscapes in a multilingual world," Annu. Rev. Appl. Linguist., vol. 33, pp. 190-212, 2013, doi: 10.1017/S0267190513000020. 